\section{The relationship between perceived face threats and class participation with respect to communication apprehension in Iranian EFL contexts}

\section{Faridizad, Ali $\bowtie$}

English Department, Najafabad branch, Islamic Azad University, Najafabad, Iran (Afaridizad26@gmail.com) Simin, Shahla

English Department, Najafabad branch, Islamic Azad University, Najafabad, Iran (shahlasimin@yahoo.com)

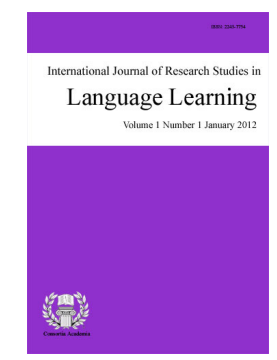

ISSN: $2243-7754$ Online ISSN: 2243-7762

OPEN ACCESS

Received: 26 January 2015

Revised: 6 February 2015

Available Online: 1 March 2015

DOI: $10.5861 /$ ijrsll.2015.1084

Accepted: 15 February 2015

\title{
Abstract
}

Classroom participation is the key to an effective communication and successful learning. There are some barriers to achieving classroom participation which may obstruct students' effective communication. In particular, Oral Communication Apprehension and Perceived Face Threats have been found to be important factors affecting classroom participation. The purpose of this study is to identify the relationship between perceived face threats and classroom participation with regard to communication apprehension in Iranian EFL Contexts. To achieve this purpose, 140 undergraduate students including 70 males and 70 females majoring in English literature, translation and teaching from Sheik-Bahai University were selected. This sample was chosen by means of simple random sampling procedure. A questionnaire was utilized as the instrument to examine the relationships among oral communication apprehension (OCA), perceived face threats (PFT) and class participation (CP). It consisted of 4 sections. The data accumulated by means of the questionnaire were analyzed to ascertain the answers to the research questions. In general, the findings indicated that students with high levels of OCA and PFT tend to experience lower frequency of CP. Moreover, the results revealed that high level of PFT was associated with high- level OCA.

Keywords: perceived face threats; oral communication apprehension; class participation 


\section{The relationship between perceived face threats and class participation with respect to communication apprehension in Iranian EFL contexts}

\section{Introduction}

In today's interconnected world, knowing English has been an indispensable part of our lives. The ultimate goal of language learning is to be able to communicate. In EFL contexts in which learners are not actually exposed to authentic language, one major way to practice communication is through class participation. To put it another way, classroom is the only place learners can have opportunities to foster and improve their communicative competence. Classroom participation can be activated significantly by the instructors through activities such as posing questions, permitting students to ask questions or offer comments, and structuring small group activities (Williams, 1971). Classroom participation includes hand rising, head nodding, sharing opinions, asking questions and generating new ideas (Burnett, 1998). Indeed, classroom participation has been found to be directly related to educational success (Jaasma, 1997). Since classroom participation is the key to effective communication and high quality of learning and success, it has been highly valued and encouraged in educational contexts (Tatar, 2005).

However, there are some obstacles to achieving classroom participation which may hinder students' effective communication. In particular, Oral Communication Apprehension (OCA) has been found to be an important factor influencing classroom participation. The concept of OCA is defined by McCroskey (1977) as "an individual level of fear or anxiety associated with either real or imagined communication with another person or persons" (p. 78). Even with high communication skill, apprehensive learners talk less and are less satisfied with their communication with others (McCroskey \& Beatty, 2000). Therefore, to improve class participation of learners, OCA has been the subject of numerous studies (Brown \& Puris, 1958; McCroskey \& Richmond, 1975; Neer \& Kirecher, 1989).

One of the reasons that may contribute to OCA is face-threatening acts. A face threatening act is the denial of one's self-image, attributes, accomplishments, and autonomy (McCroskey \& Richmond, 1975; Cupach \& Carson, 2002). The perceived face threats have been studied in terms of different variables. Some studies have examined the concept of perceived face threat across cultures (Ho, 1976; Cardon \& Scott, 2003; Yabuuchi, 2004; Liu, 2002). For example, Liu (2002) observed that face-saving was a big concern for Chinese students in U.S. classes and concluded that realizing the differences will decline the degree of perceived face threats in cross-cultural contexts. The current study attempts to constitute the existence or non-existence of the relationship between class participation and perceived face threat with respect to OCA.

\section{Literature review}

Wade (1994) considered the "ideal class discussion" as one in which all students was participating, learning, and listening to others' ideas, comments, and questions. Through another definition participation is a way to bring "students actively into the educational process" and to assist in "enhancing our teaching and bringing life to the classroom" (Cohen, 1991, p. 699).

There is strong evidence for the importance of participating in class (Lyons, 1989; Petress, 2006; Weaver \& Qi, 2005). Junn (1994) believed that participation in the class could enhance students' motivation. Weaver and Qi (2005) found that those who participate in classroom discussions regularly learn better. Another benefit stated by Kuh and Umbach (2004) was self-reported gains in characters for those who participate in the class. Moreover, a study conducted by Crone (1997) revealed that classroom participation has effects on enhancing learners' critical thinking. Students who participate in discussions also show improvement in group interactions (Armstrong \& Boud, 1983), and functioning in a democratic society (Girgin \& Stevens, 2005). 
As can be inferred from above results, although instructors, researchers, and students all appear to recognize the importance of and seemingly want to increase participation, many students do not participate for multiple reasons. There are different reasons why students avoid participating in class. One of the major reasons is class size. Gleason (1986) found that large classes tend to hamper communication among learners. Myers et al. (2009) discovered that students were more willing to participate in small class discussions in comparison to the large ones. Weaver and Qi (2005) found that in small classes students are less likely to hide. Howard, Short, and Clarck (1996) found class size to be more predictive of participation than sex. Karp and Yoels (1976) found that while the number of students who participate in any given classroom is often the same, courses which have more than 40 students have fewer overall interactions per class period.

Another reason students may not participate in class is because of their own personal fears of feeling inadequate in front of others, regardless of the logistics of the classroom setting. Armstrong and Boud (1983), Fritschner (2000), Howard and Henney (1998), Hyde and Ruth (2002), Karp and Yoels (1976), and Weaver and Qi (2005) all noted that students may feel intimidated or inadequate in front of their classmates and professors, and thus choose not to participate. Students even reported confidence as the most motivating factor for their participation in several studies (Weaver \& Qi, 2005). On top of obstacles to effective classroom participation, is instructors' behaviors. There is evidence that the instructor contributes to students' levels of participation, and students believe that their professors influence their participation based on the ways in which the professors communicate with them (Fritschner, 2000).

Several studies examined the interrelationships between people's levels of CA and their communicative behaviors. Most findings pointed out that communicative behavior of low and high communication apprehensive people differed considerably in content. Those individuals who were high in CA had the tendency to disclose less about them (McCroskey \& Richmond, 1987), had a more negative image about them and made very few positive self-statements compared to their low CA counterparts. Along the same lines, Martin, Valencic, and Heisel's (2002) study showed that college students who were apprehensive "appear to talk less overall with their instructors" (p. 5). This finding is similar to results from studies conducted by Beatty, Frost, and Stewart (1986) who report that students who exhibit high levels of CA participate fewer times in classroom activities and discussion than do their counterparts who exhibit low levels of CA.

In addition to forgoing studies, Richmond, McCroskey, and McCroskey (1989) found that people who are highly apprehensive are lonelier and tend to withdraw more from situations where communication is necessary. Moreover, according to Colby, Hopf, and Ayres (1993), for individuals who considered themselves as high CAs, it has been assumed that they "exhibit behaviors that would lessen their desirability and worth as interaction partners" (p. 222). Lederman (1983) gained unique insights into CA behaviors through the use of qualitative method. She focused on individuals with high CA to determine their actual feelings associated with talking and communicating. She found high CA individuals tended to have negative feelings and fear about talking and described it as an unpleasant activity. Also, these individuals qualified fear, pleasure, and negative self-image thoughts with the lack of talking; however, they felt more comfortable when listening and silent (Lederman, 1983).

P'Rayan and Shetty (2008) conducted a study on the overall communication apprehension of 120 engineering students in Anna University, India. The results of their study indicated that almost half of the sample groups had high CA. Their study also indicated that the mean value of communication apprehension in public speaking is the highest in comparison to group discussion, meeting and interpersonal communication. They, surprisingly, noted that even those who have high level of proficiency in a language can experience CA. Some people may be good at communicating through writing but they may have problems speaking in front of an audience. Some may be good at interpersonal communication but may not feel comfortable making presentations.

There has been limited research on CA in high school students, although some relationships between CA in 
school achievement and CA and student social acceptance in high school have been found. For example, Monroe, Borzi, and Burrell (1992) discovered that highly apprehensive students are more likely to drop out of high school than students with low apprehension. In a study in ESP context, Laurilla (2007) studied OCA in relation to oral communication activities in the Philippines. The study strived to determine levels of OCA and perceived communicative competence as well as possible correlations with particular speech acts. The results elucidated that there was no correlation between students' perception of OCA and the teacher's grades.

Atasheneh and Izadi (2012) conducted a study in Iranian context to investigate the effects of OCA on the communicative skills of listening and speaking. They found that OCA is negatively related to Iranian's performance on listening comprehension and speaking. In a research conducted by Hodis (2009), he proposed a theoretically meaningful and practically useful conceptualization of change for three communications constructs namely willingness to communicate (WTC), self-perceived communication competence, and CA. A booklet of questionnaire including three instruments (SPCC, PRCA, and WTC) was used. The findings indicated that students' WTC and SPCC scores increased linearly during the semester and CA scores decreased linearly.

Hsu (2007) conducted a study to investigate cross-cultural differences in CA with regard to cultural orientation and personality traits, the instrument used was PRCA along with negative evaluation and self-perceived competence scale. Results indicated that Taiwanese experience a higher level of CA than Americans. In a study by Ragusa (2010), the use of group work as an instructional strategy was assessed to determine the effect it had on students' willingness to communicate, OCA, and self-perceived competence. As an instrument, she used Neer's (1987) Classroom Apprehension about Participation Scale (CAPS) to collect the data. Results indicated students' willingness to communicate and self-perceived competence increased over group work instruction. It was also found that OCA was significantly reduced by using group work instruction. She concluded that group work could significantly reduce OCA and consequently increased classroom participation.

Daly and Friedrich (1981) preformed a study to compare the CA levels at home versus at school. The study questioned a student's interaction with his or her parents as well as the relationship the student has with his or her teachers. The study determined that both home and school interactions affect a student's CA level. One of the main reasons that may contribute to OCA is face threatening acts. A face threatening act is an act that inherently damages the face of the addressee or the speaker by acting in opposition to the wants and desires of the other (Brown \& Levinson, 1987). Carson and Cupach (2000) also found a strong inverse relationship between the degree of perceived face threat in the reproaches and employees' perceptions of fairness. More directly, Carson and Cupach (2000) observed that the perceived face threat of managerial reproaches was positively associated with recipient anger.

In a more recent study, Cupach and Carson (2002) conducted a study to determine whether people's reactions to complaints are a function of perceived face threat. They surveyed one hundred and ninety-nine college students asking them to describe in detail a recent complaint they had received from a friend or romantic partner, and to describe their responses to that complaint. They found the complaints delivered in public were more face threatening than complaints delivered in private and both positive and negative face threat were associated with the complaint recipient's anger/hurt and defensiveness. The findings also indicated that the face-threatening nature of complaints is associated with adverse relational consequences. Perceived threats to positive face, which tend to convey relational devaluation, were more strongly associated with relational damage than were threats to negative face.

One cross-cultural study conducted by Zheng (2008) examined the relationship between perceived face threat and classroom participation among Chinese and American college students. She collected data by means of a questionnaire. The results indicated that Chinese students experience a greater degree of perceived face threat than American students. She also found that the Chinese students tend to have lower frequency rate of classroom participation than American students. Consequently, she concluded that perceived face threat might be a factor that influences classroom participation. 
An overview of the studies presented above, demonstrates the crucial importance of classroom participation. According to McCroskey, Beatty, Kearney, and Plax (1985), if a student is apprehensive about oral communication in his/her second language, it is likely $\mathrm{s} /$ he will avoid communicating and as a result fail to experience the practices necessary to the development of true competence in the language. Thus, oral communication apprehension is mentioned as one of the factors that may hinder effective class participation. On the other hand, teachers' behavior is of paramount importance in learning language in general and students' desire to participate in particular. One of the most critical ways to study teacher's behavior is through the concept of face-threatening act. Brown and Levinson present face as "the public self-image that every member of a society wants to claim for himself/herself." (1978, p. 61). Teachers' face threatening acts may damage student's face and his desire to participate in the class.

While it seems few studies have examined the relationship between perceived face threat and classroom participation in some foreign countries, no study has specifically addressed the relationship between perceived face threats and classroom participation with respect to communication apprehension, particularly in Iranian context. Therefore, it seems conducting a study that can extend these concepts and investigates the relationship between them is necessary. In order to provide new insights into the literature, the current study attempts to constitute the existence or non-existence of the relationship between class participation and perceived face threat with respect to OCA

In fact, PFT, OCA, and CP appear to share the same cornerstone which is communication. Put is simply, all of them are manifested through communication and speech acts. Therefore, it is feasible that some sort of relationship may exist among them. The significance of this study is worth noting. This study seeks the results that are more generalizable and reliable. Thus, the results of this study may contribute to improving the relevant theories. Accordingly, the present study attempted to bridge the gap among these concepts

This study seeks to answer the following research questions:

$>\quad$ Is there any significant relationship between Iranian EFL learners' degree of oral communication apprehension and frequency of classroom participation?

$>\quad$ Is there any significant relationship between Iranian EFL learners' degree of perceived face threats and frequency of classroom participation?

$>\quad$ Is there any significant relationship between Iranian EFL learners' degree of perceived face threats and their degree of communication apprehension?

\section{Methodology}

\subsection{Participants}

The accessible population for this study included undergraduate students majoring in English literature, English translation, and English language teaching in Sheikh Bahaei University, Isfahan, Iran. The participants selected for the present study comprised 140 students. Participants were divided in two groups of male and female. Each group consisted of 70 students. The age of the participants ranged from 18 to 26 . The participants' first language was Persian. This sample was chosen from the accessible population mentioned above by means of simple random sampling procedure.

\subsection{Instruments}

The main instrument of the study is a questionnaire used to examine the relationships between perceived face threat and classroom participation. It consists of 4 sections. Each section was designed precisely to measure the specific variables of the study. 


\subsection{Validity and Reliability}

In order for an instrument to acquire sound and generalizable findings, it is overarching to be valid and reliable. Reliability of the CAPS has been evaluated by Neer (1987) using Cronbach's alpha. This study utilized Cronbach's alpha to constitute the reliability of the questionnaire. In the current study, the four items in PFT section had Cronbach's alpha of 0.86. In addition to PFT section, OCA section (CAPS) needed to be approved of reliability. Reliability of the CAPS has been evaluated using Cronbach's alpha. The internal consistency was found to be 0.94 and the CAPS was considered to be a highly reliable measure of classroom communication apprehension (Neer, 1987). In the present study, Cronbach's alpha for the 20 items in OCA section was 0.91 . Therefore, in line with Neer's study, reliability of the questionnaire was confirmed. Validity of the questionnaire was also approved. Expert judgments were employed in the current study to evaluate and confirm the validity of the questionnaire.

\subsection{Data collection}

"The survey method is one of the most important data collection methods in the social sciences, and as such it is used extensively to collect information on numerous subjects of research" (Nachmias \& Nachmias, 2007, p. 225). A survey can be through questionnaires, personal interviews, telephone surveys, or via the Internet. Therefore, a questionnaire was used for this study to examine the relationships between perceived face threats and class participation with Respect to Communication Apprehension.

\subsection{Data analysis}

The current study employed a version of the survey instrument that included only quantitative items. Thus, the survey exclusively contained closed-ended questions. The items were grouped into scales. The scales specifically examined variables addressed in the study. The data accumulated by means of the questionnaire were analyzed to determine the answers to the research questions. In so doing, the software, Statistical Packages for the Social Sciences (SPSS), was run. However, prior to conducting any required statistical procedures, item reverse coding and item computation needed to be performed.

\section{Results}

As it was noted earlier in the study, the purpose of this study was to unearth possible relationships between PFT, OCA, and CP. The study was guided by a series of research questions. The following tables indicate the descriptive and inferential statistics of results.

Answering the research Questions - The three research questions of the study mentioned below will be answered. The results also would be yielded in details.

$>\quad$ Is there any significant relationship between Iranian EFL learners' degree of perceived face threats and frequency of classroom participation?

$>\quad$ Is there any significant relationship between Iranian EFL learners' degree of perceived face threats and frequency of classroom participation?

$>$ Is there any significant relationship between Iranian EFL learners' degree of perceived face threats and their degree of communication apprehension?

\subsection{Research Question 1}

RQ 1: Is there any significant relationship between Iranian EFL learners' degree of oral communication apprehension and frequency of classroom participation? 
Relationship between perceived face threats and class participation with respect to communication apprehension

H 1: There is no significant relationship between Iranian EFL learners' degree of oral communication apprehension and frequency of classroom participation.

To investigate the relationship between OCA and CP, Pearson Correlation Coefficient was conducted. Table 1 provides the results.

Table 錯誤! 所指定的樣式的文字不存在文件中。1

Results of Pearson Correlation between OCA and CP

\begin{tabular}{lccc}
\hline & & OCA & CP \\
\cline { 2 - 3 } Pearson Correlation & Sig. (1-tailed) & $-.192^{* *}$ \\
OCA & & .001 \\
$\mathrm{~N}$ & & 140 & 140 \\
Pearson Correlation & Sig. (1-tailed) & $-.192^{* *}$ & 1 \\
$\mathrm{CP}$ & .001 & \\
$\mathrm{~N}$ & 140 & 140 \\
\hline Note. ${ }^{* *}$ Correlation is significant at the 0.01 level (1-tailed) & &
\end{tabular}

As it can be seen in table 4.1, there is a strong negative correlation between learners' degree of OCA and frequency of $\mathrm{CP}(\mathrm{r}=-.92 p<.01)$. The observed negative correlation suggests that students with high levels of OCA tend to experience lower frequency of $\mathrm{CP}$. Thus, based on the results presented in table 1 , the first null hypothesis failed to be supported.

\subsection{Research Question 2}

RQ 2 Is there any significant relationship between Iranian EFL learners' degree of perceived face threats and frequency of classroom participation?

H 2: There is no significant relationship between Iranian EFL learners' degree of perceived face threats and frequency of classroom participation.

In order to answer research question 2, Pearson Correlation Coefficient tested the relationship between PFT and CP. Table 2 shows the results.

Table 錯誤! 所指定的樣式的文字不存在文件中。2

Results of Pearson Correlation between PFT and CP

\begin{tabular}{|c|c|c|c|}
\hline & & PFT & $\mathrm{CP}$ \\
\hline Pearson Correlation & & 1 & $-.263^{*}$ \\
\hline PFT & Sig. (1-tailed) & & .000 \\
\hline $\mathrm{N}$ & & 140 & 140 \\
\hline Pearson Correlation & & $-.263^{*}$ & 1 \\
\hline $\mathrm{CP}$ & Sig. (1-tailed $)$ & .000 & \\
\hline $\mathrm{N}$ & & 140 & 140 \\
\hline
\end{tabular}


Faridizad, A., \& Simin, S.

As displayed in table 2, there is a strong negative correlation between learners' degree of PFT and frequency of CP ( $\mathrm{r}=-.263 p<.01)$, with high degree of PFT associated with lower frequency of CP. Therefore, the second hypothesis is rejected.

\subsection{Research Question 3}

RQ 3: Is there any significant relationship between Iranian EFL learners' degree of perceived face threats and their degree of communication apprehension?

H 3: There is no significant relationship between Iranian EFL learners' degree of perceived face threats and their degree of communication apprehension.

In order to find a plausible answer to the research question three mentioned above, Pearson-product Correlation Coefficient (one-tailed) was adopted. Table 3 presents the results.

Table 錯誤! 所指定的樣式的文字不存在文件中。3

Results of Pearson Correlation between PFT and OCA

\begin{tabular}{|c|c|c|c|}
\hline & & PFT & OCA \\
\hline Pearson Correlation & & 1 & $.133^{*}$ \\
\hline PFT & Sig. (1-tailed) & & .016 \\
\hline $\mathrm{N}$ & & 140 & 140 \\
\hline Pearson Correlation & & $.133^{*}$ & 1 \\
\hline OCA & Sig. (1-tailed) & .016 & \\
\hline $\mathrm{N}$ & & 140 & 140 \\
\hline
\end{tabular}

Note. *Correlation is significant at the 0.05 level (1-tailed)

Table 3 reveals that there is a significant positive correlation between learners' degree of PFT and OCA $(\mathrm{r}=.133 p<.05)$, with high levels of PFT associated with high levels of OCA. Thus, the third null hypothesis is also rejected.

\section{Discussion and Conclusion}

The present study delved deeply into the issues of $\mathrm{CP}$ and the factors that might affect students' effective $\mathrm{CP}$. More specifically, this study was constructed to unveil, firstly, the relationship between PFT and OCA and, secondly, their relationships with CP. 140 participants from Sheikh Bahai University were surveyed. Statistical analyses were done via both bivariate procedures. Upon the analyses of the data, the researcher found PFT and OCA having significant relationship with $\mathrm{CP}$. Several conclusions could be drawn upon the findings. One major conclusion is that the more EFL students perceive a classroom situation as face threatening, the less they participate in classroom discussions. The next conclusion, also, refers to the inverse relationship between OCA and $\mathrm{CP}$ indicating that apprehensive students are less willing to take part in class activities. To sum it up, the present study yielded overarching findings upon which significant conclusions can be drawn such as identifying certain factors tending to jeopardize effective CP. Hence, the upshots of the study appear to be quite promising to help educators and researchers give $\mathrm{CP}$ more careful considerations.

\subsection{Implications}

The outcomes about the relationship between PFT and CP provide new insights into the factors affecting CP and open the avenues for further research in the field. Additionally, the negative correlation between learners' 
Relationship between perceived face threats and class participation with respect to communication apprehension degree of OCA and CP was supported by the majority of the studies such as Miller (1995), Elias (1999), Johnson and Faunce (1973), Aly and Islam (2005), McCroskey, Simpson, and Richmond (1982), Frantz, Marlow, and Wathen (2005), and Rashidi, Yamini, and Shafiei (2010).

The results of the current study can contribute greatly to positive educational changes by helping educators and instructors, first, understand the detrimental effects of OCA and PFT and, second, employ efficient methods and techniques to optimize effective classroom participation. Planning upon the major findings of the study concerning learners' degree of PFT, teachers should make hard efforts to create non-face threatening situations. The current study employed teacher's features and behavior, i.e. age, degree, and intimacy of the relationship as the basis to examine students' perceptions of face threat. Then, upon the outcomes of this instrument some suggestions can be offered to create non-face threatening classrooms. For instance, teachers should be encouraged to increase face-to-face interactions with students out of the class. Moreover, teachers' availability and responsiveness should be cajoled. Arising from the findings of the study about OCA, teachers should endeavor to reduce OCA in their students. Qin (2003) suggests teachers should be aware of learners' personality factors because these factors are attached to students' anxiety. $\mathrm{Na}$ (2007) recommends that teachers should avoid negative evaluation of students. Instead, teachers should employ more encouragements and praises. Furthermore, Tok (2009) advises teachers to offer apprehensive students numerous opportunities to speak up to improve students' engagement. This can be done through building group works (Ragusa, 2010), permitting voluntary seating choices (McCroskey, 1977), and calling on students in a non-threatening manner such as by first names (Tok, 2009).

\section{References}

Armstrong, M., \& Boud, D. (1983). Assessing participation in discussion: An exploration of the issues. Studies in Higher Education, 8(1), 33-44. http://dx.doi.org/10.1080/03075078312331379101

Atasheneh, N., \& Izadi, A. (2012). The role of teachers in reducing/increasing listening comprehension test anxiety: A case of Iranian EFL learners. English Language Teaching, 5(3), 178-187. http://dx.doi.org/10.5539/elt.v5n3p178

Brown, P., \& Levinson, S. C. (1978). Universals in language usage: Politeness phenomena. In Questions and politeness: Strategies in social interaction (pp. 56-311). Cambridge University Press.

Brown, P., \& Levinson, S. C. (1987). Politeness: Some universals in language usage (Vol. 4): Cambridge University Press.

Carson, C. L., \& Cupach, W. R. (2000). Facing corrections in the workplace: The influence of perceived face threat on the consequences of managerial reproaches. Journal of Applied Communication Research, 28, 215-234. http://dx.doi.org/10.1080/00909880009365572

Cohen, M. (1991). Making class participation a reality. Political Science and Politics, 24(4), 699-703. http://dx.doi.org/10.1017/S1049096500051957

Colby, N., Hopf, T., \& Ayres, J. (1993). Nice to meet you? Inter/Intrapersonal perceptions of communication apprehension in initial interactions. Communication Quarterly, 41(2), 221-230. http://dx.doi.org/10.1080/01463379309369881

Crone, J. A. (1997) Using panel debates to increase student involvement in the introductory sociology class . Teaching Sociology, 25(3), 214-218. http://dx.doi.org/10.2307/1319397

Cupach, W. R., \& Carson, C. L. (2002). Characteristics and consequences of interpersonal complaints associated with perceived face threat. Journal of Social and Personal Relationships, 19(4), 443-462. http://dx.doi.org/10.1177/0265407502019004047

Daly, J. A., \& Friedrich, G. (1981). The development of communication apprehension: A retrospective analysis of contributory correlates.Communication Quarterly, 29(4), 243-255. http://dx.doi.org/10.1080/01463378109369412

Fritschner, L. M. (2000). Inside the undergraduate college classroom: Faculty and students differ on the meaning of student participation. The Journal of Higher Education, 71, 342-362. 
Faridizad, A., \& Simin, S.

http://dx.doi.org/10.2307/2649294

Girgin, K. Z., \& Stevens, D. D.(2005). Bridging in-class participation with innovative instruction: Use and implications in a Turkish university classroom. Innovations in Education and Teaching International, 42(1), 93-106. http://dx.doi.org/10.1080/14703290500049059

Gleason, M. (1986). Better communication in large classes. College Teaching, 34(1), 20-24. http://dx.doi.org/10.1080/87567555.1986.10532325

Hodis, G. M. (2009). A longitudinal latent growth modeling perspective on communication apprehension, self-perceived communication competence, and willingness to communicate. Southern Illinois University, Carbondale, Illinois.

Howard, J. R., \& Henney, A. L. (1998). Student participation and instructor gender in the mixed-age college classroom. The Journal of Higher Education, 73(6), 764-780. http://dx.doi.org/10.1353/jhe.2002.0052

Howard, J. R., Short, L. B., \& Clark, S. M. (1996). Students' participation in the mixed -age college classroom. Teaching Sociology, 24, 8-24. http://dx.doi.org/10.2307/1318894

Hsu, C. F. (2007). A cross-cultural comparison of communication orientations between Americans and Taiwanese. Communication quarterly, 55(3), 359-374. http://dx.doi.org/10.1080/01463370701497831

Hyde, C. A., \& Ruth, B. J. (2002). Multicultural content and class participation: Do students self-disclose? Journal of Social Work Education, 38(2), 241-256.

Junn, E. (1994). Pearls of wisdom: Enhancing student class participation with an innovative exercise. Journal of Instructional Psychology, 21, 385-387.

Karp, D. A., \& Yoels, W. C. (1976). The college classroom: Some observations on the meanings of student participation. Sociology and Social Research, 60, 421-439.

Kuh, G. D., \& Umbach, P. D. (2004). College and character: Insights from the National Survey of Student Engagement. New Directions for Institutional Research, 122, 37-54. http://dx.doi.org/10.1002/ir.108

Lederman, L. C. (1983). High communication apprehensives talk about communication apprehension and its effects on their behavior. Communication Quarterly, 31(3), 233-237. http://dx.doi.org/10.1080/01463378309369509

Lyons, P. R. (1989). Assesing classroom participation College Teaching, 37(1), 36-38. http://dx.doi.org/10.1080/87567555.1989.10532154

Martin, M. M., Valencic, K. M., \& Heisel, A. D. (2002). The relationship between students' communication apprehension and their motives for communicating with their instructors. Communication Research Reports, 19(1), 1-7. http://dx.doi.org/10.1080/08824090209384826

McCroskey, J. C., (1984). The communication apprehension perspective. In J. A. Daly \& J.C. McCroskey, Avoiding communication: Shyness, reticence, and communication apprehension (pp. 13-38). Beverly Hills, CA: Sage.

McCroskey, J. C., \& Richmond, V. P. (1987). Willingness to communicate. Personality and interpersonal communication, 6, 1-11.

McCroskey, J. C., Beatty, M. J., Kearney, P., \& Plax, T. G. (1985). The content validity of the PRCA-24 as a measure of communication apprehension across communication contexts. Communication Quarterly, 33(3), 165-173. http://dx.doi.org/10.1080/01463378509369595

Monroe, C., Borzi, M. G., \& Burrell, R. D. (1992). Communication apprehension among high school dropouts. The School Counselor, 39(4), 273-280.

Myers, S. A., Horan, S. M., Kennedy-lightsey, C. D., Madlock, P. E., Sidelinger, R. J., Byrnes, K., Frisby, B., \& Mansson, D. H. (2009). The relationship between college students'self -reports of class participation and perceived instructor impressions. communication Research Reports, 26, 123-133. http://dx.doi.org/10.1080/08824090902861580

Neer, M. R. (1987). The development of an instrument to measure classroom apprehension. Communication Education, 36(2), 154-166. http://dx.doi.org/10.1080/03634528709378656

Petress, K. (2006). An operational defenition of class participation. College Student Journal, 40(4), 821-823.

P'Rayan, A., \& Shetty, R. T. (2008). Developing engineering students' communication skills by reducing their communication apprehension. English for Specific Purposes World, 4(20), 1-24. 
Relationship between perceived face threats and class participation with respect to communication apprehension

Ragusa, S. R. (2010). Examining the relationship between group work and students' willingness to participate Doctoral dissertation, Kansas State University.

Richmond, V. P., McCroskey, J. C., \& McCroskey, L. L. (1989). An investigation of self-perceived communication competence and personality orientations. Communication Research Reports, 6(1), 28-36. http://dx.doi.org/10.1080/08824098909359829

Rojo-Laurilla, M. A. (2007). Communication apprehension and communicative competence among maritime students in the Philippines. Journal of Reflections on English Language Teaching, 6(2), 39-58.

Wade, R. (1994). Teacher education students'views on classroom discussion: Implications for fostering critical reflection. Teaching and Teacher Education, 10(2), 231-243. http://dx.doi.org/10.1016/0742-051X(94)90015-9

Weaver, R. R., \& Qi, J. (2005).classroom organization and participation: college students' perception. The Journal of Higher Education, 76(5), 570-601. http://dx.doi.org/10.1353/jhe.2005.0038

Zheng, A. (2008, May). Percieved face threat in classroom participation: A comparison of Chinese and US Americans. Paper presented at the annual meeting of the International Communication Association: Montreal, Canada. 
Faridizad, A., \& Simin, S. 